\title{
Rhizosphere bacterial communities of potato cultivars evaluated through PCR-DGGE profiles
}

\author{
Enderson Petrônio de Brito Ferreira(1), André Nepomuceno Dusi(2), \\ Gustavo Ribeiro Xavier ${ }^{(3)}$ and Norma Gouvêa Rumjanek ${ }^{(3)}$
}

\begin{abstract}
(1)Embrapa Arroz e Feijão, Caixa Postal 179, CEP 75375-000 Santo Antônio de Goiás, GO, Brazil. E-mail: enderson@cnpaf.embrapa.br (2)Embrapa Hortaliças, Caixa Postal 218, CEP 70359-970 Gama, DF, Brazil. E-mail: dusi@cnph.embrapa.br (3)Embrapa Agrobiologia, Caixa Postal 74.505, CEP 23890-000 Seropédica, RJ, Brazil. E-mail: gustavo@cnpab.embrapa.br, norma@cnpab.embrapa.br
\end{abstract}

\begin{abstract}
The objective of this work was to determine the shifts on the PCR-DGGE profiles of bacterial communities associated to the rhizosphere of potato cultivars, in order to generate baseline information for further studies of environmental risk assessment of genetically modified potato plants. A greenhouse experiment was carried out with five potato cultivars (Achat, Bintje, Agata, Monalisa and Asterix), cultivated in pots containing soil from an integrated system for agroecological production. The experiment was conducted in a split plot randomized block design with five cultivars, three sampling periods and five replicates. Rhizosphere samples were collected in three sampling dates during plant development. DNA of rhizosphere microorganisms was extracted, amplified by PCR using bacterial universal primers, and analyzed through DGGE. Shifts on the rhizosphere bacterial communities associated to rhizosphere of different cultivars were related to both cultivar and plant age. Differences among rhizosphere bacterial communities were clearest at the earliest plant age, tending to decrease in later stages. This variation was detected among bacterial communities of the five tested cultivars. The characterization of soil microbial communities can be part of plant breeding programs to be used on studies of environmental risk assessment of genetically modified potatoes.
\end{abstract}

Index terms: Solanum tuberosum, associative bacteria, molecular marker, PCA.

\section{Comunidades bacterianas associadas à rizosfera de cultivares de batata avaliadas por perfis de PCR-DGGE}

\begin{abstract}
Resumo - O objetivo deste trabalho foi determinar as alterações nos perfis de PCR-DGGE das comunidades bacterianas associadas à rizosfera de cultivares de batata, para obter informações para futuros estudos de avaliação de risco ambiental de plantas de batatas geneticamente modificadas. Foi conduzido experimento em casa de vegetação com cinco cultivares de batata (Achat, Bintje, Ágata, Monalisa e Asterix), cultivadas em vasos com solo de um sistema integrado de produção agroecológica. O delineamento experimental foi o de blocos ao acaso, em parcelas subdivididas, com cinco cultivares, três períodos amostrais e cinco repetições. As amostras de rizosfera foram coletadas em três diferentes épocas durante o desenvolvimento das plantas. O DNA dos microrganismos associados à rizosfera foi extraído, amplificado por PCR com uso de iniciadores universais para bactérias e analisados por DGGE. Foram observadas alterações, relacionadas à cultivar e à idade da planta, nos perfis das comunidades bacterianas associadas à rizosfera das diferentes cultivares. As diferenças entre as comunidades bacterianas foram maiores na fase inicial do crescimento das plantas, com tendência a diminuir no estágio final de desenvolvimento. Essa variação foi detectada na comunidade bacteriana das cinco cultivares estudadas. A caracterização da microbiota do solo pode ser parte de programas de melhoramento de plantas a ser utilizada em estudos de avaliação de risco ambiental de batatas geneticamente modificadas.
\end{abstract}

Termos para indexação: Solanum tuberosum, bactérias associativas, marcador molecular, PCA.

\section{Introduction}

Many countries worldwide have commercial production of genetically modified (GM) crops. The adoption of GM plants in the agricultural scenario aimed to improve yield production, through the incorporation of interesting agronomical traits and by the introduction of genes resistant to pest and diseases. However, most GM crops released under field conditions were not preceded by environment-specific biosafety studies, which today are considered of great importance for the reduction of environmental risks (Hilbeck \& Andow, 2004). 
Despite the role of potato crop in the world economic scenario, studies about its interactions with microbial communities are scarce. Since 1996, Embrapa developed a transgenic potato clone resistant to Potato virus $Y$ (PVY), and the environmental risk assessment studies of this clone are underway. The relationship between plants and soil microbial community is very complex and occurs in many ways, resulting in beneficial effects such as stimulation of plant hormones synthesis and enhancement of biological nitrogen fixation and phosphate solubilization, or in negative effects like occurrence of diseases.

According to Sung et al. (2006), plants are capable to increase soil microbial population through root exudates, which are used by microorganisms as nutrient source for their growth. The chemical composition of root exudates vary not only among different plant species, but also among cultivars of the same plant species (Grayer et al., 2004; Kato-Noguchi \& Ino, 2005; Kerdchoechuen, 2005). Besides, the chemical composition of root exudates is a result of different factor interactions, such as nutritional status, age, stress, diseases, and environmental factors that affect the microbial community associated to the rhizosphere (Mahaffee \& Kloepper, 1997; Griffiths et al., 1999).

Different cultivars of the same species might present some physiological differences. Therefore, when cultivated under the same cropping conditions, they can potentially promote the selection of distinct microbial community associated to the plant tissues (Gomes et al., 2003), since microbial communities depend on plant cultivars (Silva et al., 2003). This suggests that part of these shifts on the microbial communities occurs due to direct interaction with the plants, or due to the stress occurred in the plants (MacDonald et al., 2004).

This objective this work was to determine the shifts on the PCR-DGGE profiles of bacterial communities associated to rhizosphere of different commercial potato cultivars, in order to generate baseline information for further studies of environmental risk assessment of GM potato plants.

\section{Materials and Methods}

The soil used in this experiment was collected from an agroecological integrated production system area, in the county of Seropédica, RJ, Brazil. The experiment was carried out under greenhouse conditions, with five replicates, in a split plot randomized block design with five potato cultivars (Table 1), and three sampling periods: 15 days after germination (DAG), corresponding to the final stage of germination; $30 \mathrm{DAG}$, corresponding to the vegetative development stage; and $60 \mathrm{DAG}$, related to the reproductive stage. The tubers were planted in pots containing $1.5 \mathrm{~kg}$ of soil, three plants per parcel, once the root sampling procedure was a destructive method. The tuber-seeds were produced at Embrapa

Table 1. Morpho-physiological characteristics of potato cultivars ${ }^{(1)}$.

\begin{tabular}{|c|c|c|c|c|c|}
\hline Characteristic & Achat & Bintje & Agata & Monalisa & Asterix \\
\hline \multicolumn{6}{|l|}{ Stem } \\
\hline Vigor & Little & Much & Little & Medium & Medium \\
\hline Number & 4 to 5 & 3 to 4 & 8 to 10 & 5 to 6 & 4 to 5 \\
\hline Leaf size & Small & Larg & Medium & Larg & Medium \\
\hline Leaf color & Dark green & Dark green & Light green & Light green & Light green \\
\hline Plant height & Medium & Medium-tall & Short & Tall & Tall \\
\hline Cycle & Semi-early & Late & Early & Early & Semi-late \\
\hline Flowering & No & Yes & Yes & Yes & Yes \\
\hline Flower color & - & White & White & White & Redish purple \\
\hline \multicolumn{6}{|l|}{ Tuber } \\
\hline Shape & Elongated flat & Elongated oval & Oval & Elongated & Elongated oval \\
\hline Skin color & Light yellow & Light yellow & Purple yellow & Yellow & Red \\
\hline Texture & Smooth fosca & Smooth bright & Smooth bright & Smooth bright & Rough \\
\hline Eyes & Shallow & Shallow & Shallow & Shallow & Deep \\
\hline Pulp color & Pale yellow & Pale yellow & Pale yellow & Yellow & Yellow \\
\hline \multicolumn{6}{|l|}{ Sprout } \\
\hline Color & Redish purple & Blueish purple & Light redish purple & Redish purple & Redish purple \\
\hline \multicolumn{6}{|l|}{ Diseases } \\
\hline Early-blight $^{(2)}$ & Resistant & Susceptible & Susceptible & Moderate resistance & Moderate resistance \\
\hline PLRV & Susceptible & Susceptible & Moderate resistance & Moderate resistance & Moderate resistance \\
\hline PVY & Resistant & Susceptible & Moderate susceptibility & Moderate susceptibility & Resistant \\
\hline
\end{tabular}

(1)Adapted of: Jabuomski \& Furumoto (1997); Ávila et al. (1999); Nivaa (2003); Abba (2005). (2)Phytophthora infestans. 
Hortaliças (Embrapa Vegetables) and were indexed as free of virus and other pests.

The plant roots were taken from the pots and gently separated from the bulk soil. The roots were carefully washed with autoclaved saline solution $(\mathrm{NaCl} 0.85 \%)$, in order to eliminate the excess of rhizospheric soil, and were placed on autoclaved absorbent paper to remove the excess of water. Then, $1 \mathrm{~g}$ of washed roots was placed in a $50 \mathrm{~mL}$ falcon tube containing $20 \mathrm{~mL}$ of sterile saline solution. Samples were shaken at $150 \mathrm{rpm}$ for $30 \mathrm{~min}$, and an aliquot of $8 \mathrm{~mL}$ was transferred to a $15 \mathrm{~mL}$ falcon tube, followed by centrifugation at $9,000 \mathrm{~g}$ for $30 \mathrm{~min}$ at $4{ }^{\circ} \mathrm{C}$. The supernatant was discarded, and the pellet was raised in $1 \mathrm{~mL}$ of sterile water and vortexed. The bacterial cells suspension was transferred to a $1.5 \mathrm{~mL}$ microtube and centrifuged as described above for $15 \mathrm{~min}$. The supernatant was discarded and the pellet stored at $-20^{\circ} \mathrm{C}$.

DNA extraction was performed according to the protocol described by Schwieger \& Tebbe (1998) and modified by Xavier et al. (2004). The stored pellets were raised in $0.6 \mathrm{~mL}$ of TES buffer $(0.05 \mathrm{M} \mathrm{NaCl}$; 0.01M EDTA; 0.05M Tris $\mathrm{HCl} \mathrm{pH} \mathrm{8;} 1 \%$ SDS) and vortexed. Samples were submitted to five freezing and thawing cycles, consisting of freezing in liquid nitrogen (5 min) and heating under agitation $\left(65^{\circ} \mathrm{C} ; 180 \mathrm{RPM}\right.$; $5 \mathrm{~min}$ ). Between each step, samples were mixed by vortexing. Then, $8.4 \mu \mathrm{L}$ of proteinase $\mathrm{K}\left(20 \mathrm{mg} \mathrm{mL}^{-1}\right)$ were added to each sample, followed by incubation under agitation $\left(65^{\circ} \mathrm{C} ; 180 \mathrm{RPM} ; 1\right.$ hour $)$. After the incubation time, $0.6 \mathrm{~mL}$ of phenol, chloroform and isoamilic alcohol (25:24:1) was added to each sample and centrifuged $(7,500 \mathrm{~g} ; 6 \mathrm{~min})$. The supernatant was transferred to a $1.5 \mathrm{~mL}$ microtube, and $0.6 \mathrm{~mL}$ of chloroform and isoamilic alcohol $(24: 1)$ was added, followed by centrifugation $(7,500 \mathrm{~g} ; 6 \mathrm{~min})$. A $0.5 \mathrm{~mL}$ aliquot of the supernatant was transferred to a $1.5 \mathrm{~mL}$ microtube, and $0.5 \mathrm{~mL}$ of cold isopropanol was added. The samples were incubated at $-20^{\circ} \mathrm{C}$ for $60 \mathrm{~min}$, and centrifuged $(16,100 \mathrm{~g} ; 20 \mathrm{~min})$. The supernatant was removed, and the pellet was dried in a cold trap centrifuge and raised in $50 \mu \mathrm{L}$ of TE buffer $(10 \mathrm{mM}$ Tris; $1 \mathrm{mM}$ Na-EDTA; $\mathrm{pH} 8$ ).

The PCR was performed with three different dilutions of the DNA samples: 1:20, 1:40 and 1:80 in ultrapure water. For each DNA dilution, PCR amplification was carried out on a final volume of $35 \mu \mathrm{L}$, containing $1 \mu \mathrm{L}$ DNA dilution, PCR buffer (1X), $\mathrm{MgCl}_{2}(1.5 \mathrm{mM})$, dNTP $(0.2 \mu \mathrm{M}$ of each), bovine serum albumin $\left(0.17 \mu \mathrm{g} \mu \mathrm{L}^{-1}\right), \mathrm{Taq}$ DNA polymerase $(0.7 \mathrm{U})$, and the set of primers $1401-\mathrm{R}$ and $968 \mathrm{CG}-\mathrm{F}(0.2 \mu \mathrm{M}$ of each). These primers and PCR program were described by Gelsomino et al. (1999). The amplified products of each replicate were mixed together in a single microtube.

To determine the best denaturing conditions for the samples, a preliminary assay was performed with $6 \%$ poliacrylamide gel, containing from zero to $100 \%$ of $7 \mathrm{M}$ urea and $40 \%$ formamide. The best denaturing conditions were between 50 and $65 \%$ of the denaturing agents. For the assays, 50 to $65 \%$ denaturing gels were prepared by mixing two solutions, the first one containing $3.5 \mathrm{M}$ urea and $20 \%$ formamide, and the second containing 4.55 $\mathrm{M}$ urea and $26 \%$ formamide. Depending on the efficiency of PCR amplification, 12 to $20 \mu \mathrm{L}$ of the mixed amplified products were loaded in denaturing poliacrylamide gel 6\% (N-acrylamide, N'-metilbisacrylamide, 37:1), in $0.5 X$ TAE buffer final concentration: (Tris-acetate $20 \mathrm{mM}$ and EDTA $0.5 \mathrm{mM}$ ). The electrophoresis was carried out in a Dcode Detection Mutation System, under constant voltage $\left(120 \mathrm{~V} ; 60^{\circ} \mathrm{C} ; 16\right.$ hours $)$. Gels were stained using SYBR Gold (20X), and were visualized under UV light in an IMAGO photo-documentation system.

Binary matrixes based on the PCR-DGGE profiles for each replicate were created according to Kozdrój \& Elsas (2001). The similarity matrixes of the five replicates were combined later to compose a single similarity matrix (Aboim et al., 2008) to be used on the similarity clustering and principal component analysis (PCA). The clustering analysis was performed using the Jaccard index and UPGMA method.

\section{Results and Discussion}

The bacterial community profiles associated to the rhizosphere of different cultivars at 15,30 and 60 DAG are in Figure 1. Some bands (arrows) occur in all cultivars, in all evaluation dates. However, some bands (circles) are dependent on the cultivar or even development stage of the plant.

The bands indicated by arrows in the PCR-DGGE profiles (Figure 1) occur in all cultivars and sampling dates, suggesting that those bands are associated with unspecific bacterial groups associated with the rhizosphere of the plants. These profiles might be associated with bacterial groups such as growth promoters affected by the rhizosphere and being beneficial to plants (Bushby et al., 1993; Roesti et al., 2006).

The PCR-DGGE profile of bands of specific cultivars or their developmental stages, indicated by the circles at Figure 1, suggests that those bands were originated from 
more specific bacterial groups, which are selected by the plants due to different root exudates. It has been observed that different cultivars of the same plant species exudate different amounts (Kato-Noguchi \& Ino, 2005) and compounds (Grayer et al., 2004; Kerdchoechuen, 2005) that might be related to the observed shifts of microbial communities associated to the rhizoplane of these plants (Gu \& Mazzola, 2003).

A study was conducted with Trifolium repens and Lolium perenne, in which the rhizosphere was divided into three different compartments (soil, rhizospheric soil and rhizoplane). The soil fraction was mostly colonized by gram-positive bacterial species, Cytophagal
Flexibacter/Bacteroides (CFB group), Proteobacteria and Holophaga/Acidobacterium. At the rhizosplane and rhizospheric soil fractions, a selective effect favored the gama-Proteobacteria prior to the gram-positive and Holophaga/Acidobacterium, leading to the prevalence of the Pseudomonas bacterial group (Marilley \& Aragno, 1999). These authors also observed that the phylogenetic diversity diminishes, as the samples are collected nearer to plant roots. Bacteria belonging to the Pseudomonas group are known as growth promoters (Gupta et al., 2005; Picard \& Bosco, 2005), although some species or even some strains cause diseases or interfere negatively with plant development (Berggren et al., 2005).
A

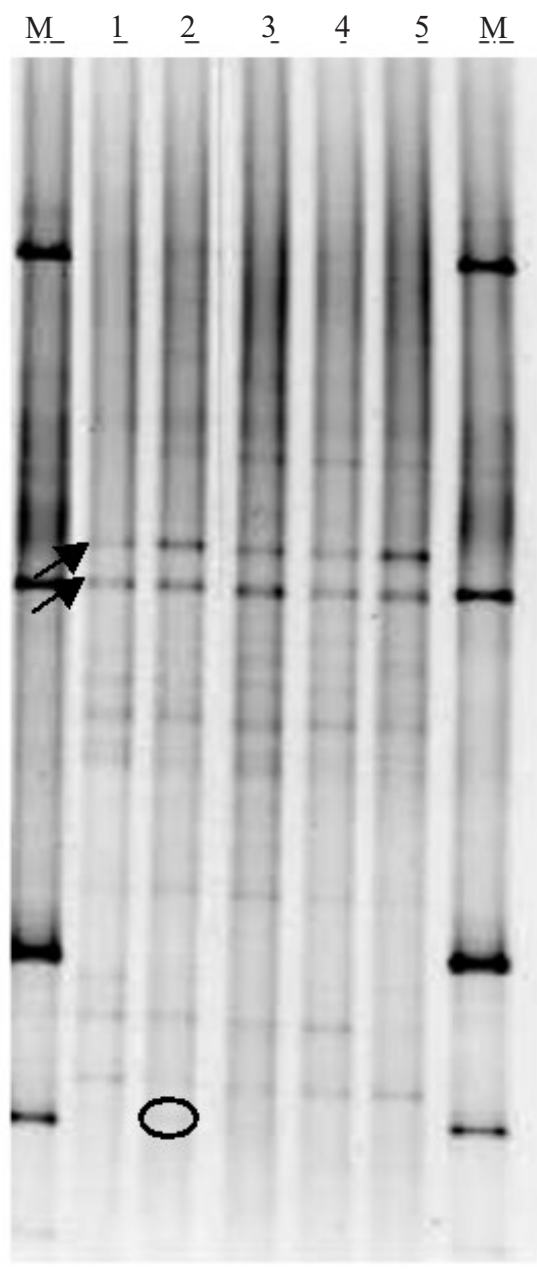

B

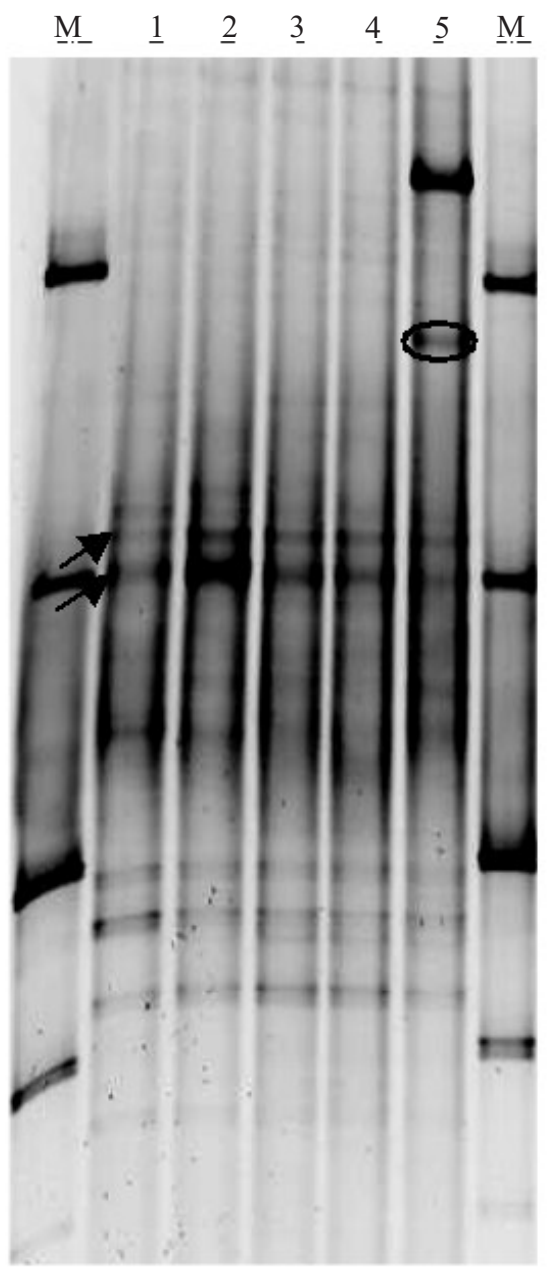

$\mathrm{C}$

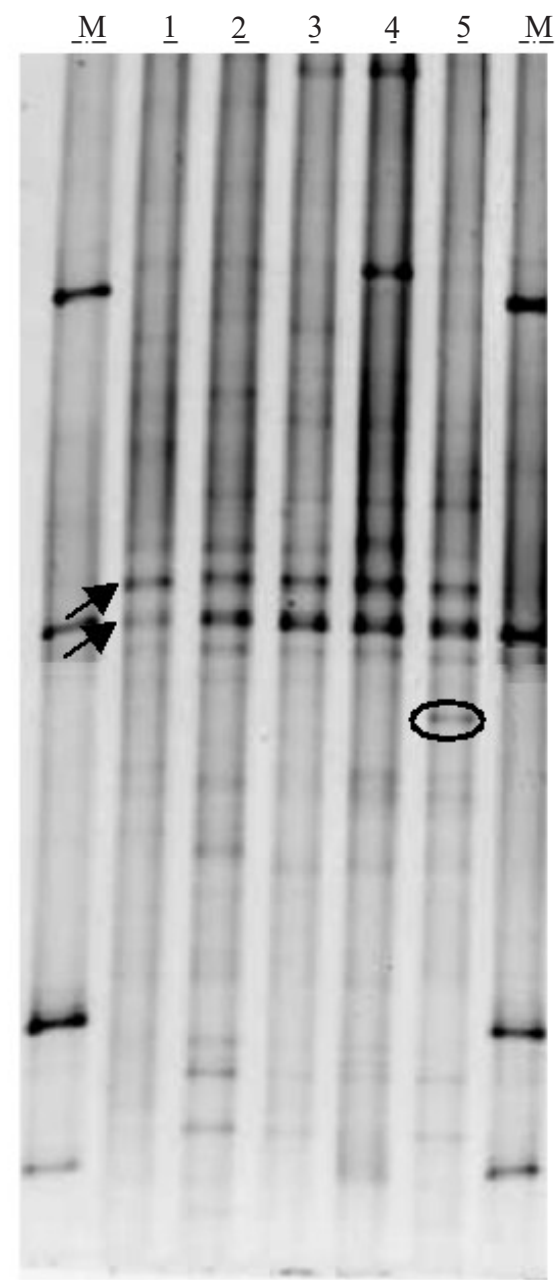

Figure 1. PCR-DGGE profiles of the bacterial communities associated to the rhizosphere of the different potato cultivars. A, first sampling date; B, second sampling date; C, trird sampling date. M, marker (from top to bottom: Bradyrhizobium elkanii BR 113, Sinorhizobium fredii BR 112, Mesorhizobium plurifarium BR 3804 and Burkholderia sp. BR 11340); 1, Achat; 2, Bintje; 3, Agata; 4, Monalisa; 5, Asterix. 
Olsson \& Persson (1999) reported the higher adherence of the soil to the roots of barley as a factor of increase of the CFB bacterial group, and of decrease of the Pseudomonas group, in rhizospheric soil.

Based on the PCR-DGGE profiles, dendrograms representing the bacterial communities at different sampling dates were drawn (Figure 2). Although tuber formation could be observed at $60 \mathrm{DAG}$, their developmental stage differed from one cultivar to another. Also, depending on the cultivar, the mother tubers were already decomposed, such as observed for 'Asterix' and 'Monalisa'.

'Asterix' and 'Monalisa' were grouped in the first and second sampling dates (Figure $2 \mathrm{~A}$ and B), with an average similarity of $65 \%$. In the third sampling date, these cultivars split to different groups, with a similarity of 35\%. 'Asterix' and 'Achat' were in the same group in all sampling dates, with 53, 65 and $40 \%$ for the first, second and third sampling dates, respectively. 'Agata' had the lowest similarity rates being placed apart from the other cultivars, in all sampling dates. Although the similarity indexes varied among the sampling dates (48, 60 and $36 \%$ in the first, second and third sampling dates, respectively; Figure $2 \mathrm{~A}, \mathrm{~B}$ and $\mathrm{C}$ ), a general reduction trend was observed during the plants development, associated with the decomposition of the mother-tubers.

A reduction on the similarity index was observed in the third sampling date (Figure $2 \mathrm{C}$ ). The highest similarity was $43 \%$ between 'Asterix' and 'Achat', and the lowest similarity was $35 \%$ between the two clusters - first cluster: 'Achat', 'Asterix' and 'Bintje'; second cluster: 'Agata' and 'Monalisa' (Figure 2 C) -, resulting in a difference of $7 \%$ similarity. Using the same approach for the data from 15 DAG (Figure $2 \mathrm{~A}$ ), the difference between the two clusters and the highest similarity between two cultivars is around $17 \%$, indicating that at this stage bacterial communities are more easily distinguished than at later developmental stages of the plant.

The bacterial community composition of 'Monalisa' and 'Asterix' rhizosphere, considering the phylogenetic dendrogram (Figure $2 \mathrm{~A}$ and B), was more similar at the first and second sampling dates. This suggests that their root exudates might be selecting more similar bacterial groups, when comparing with the other cultivars. Usually, a higher influence of the plant on the rhizosphere associated microbial communities is observed at the early stages of development (Gomes et al., 2003; Ibekwe \& Grieve, 2004).
'Monalisa' and 'Agata' presented the mother-tuber at an advanced decomposition stage prior to the other cultivars. This might have stimulated specific saprophytic bacterial groups to develop. Also, the variation in the diversity of the group formation, at each sampling date,

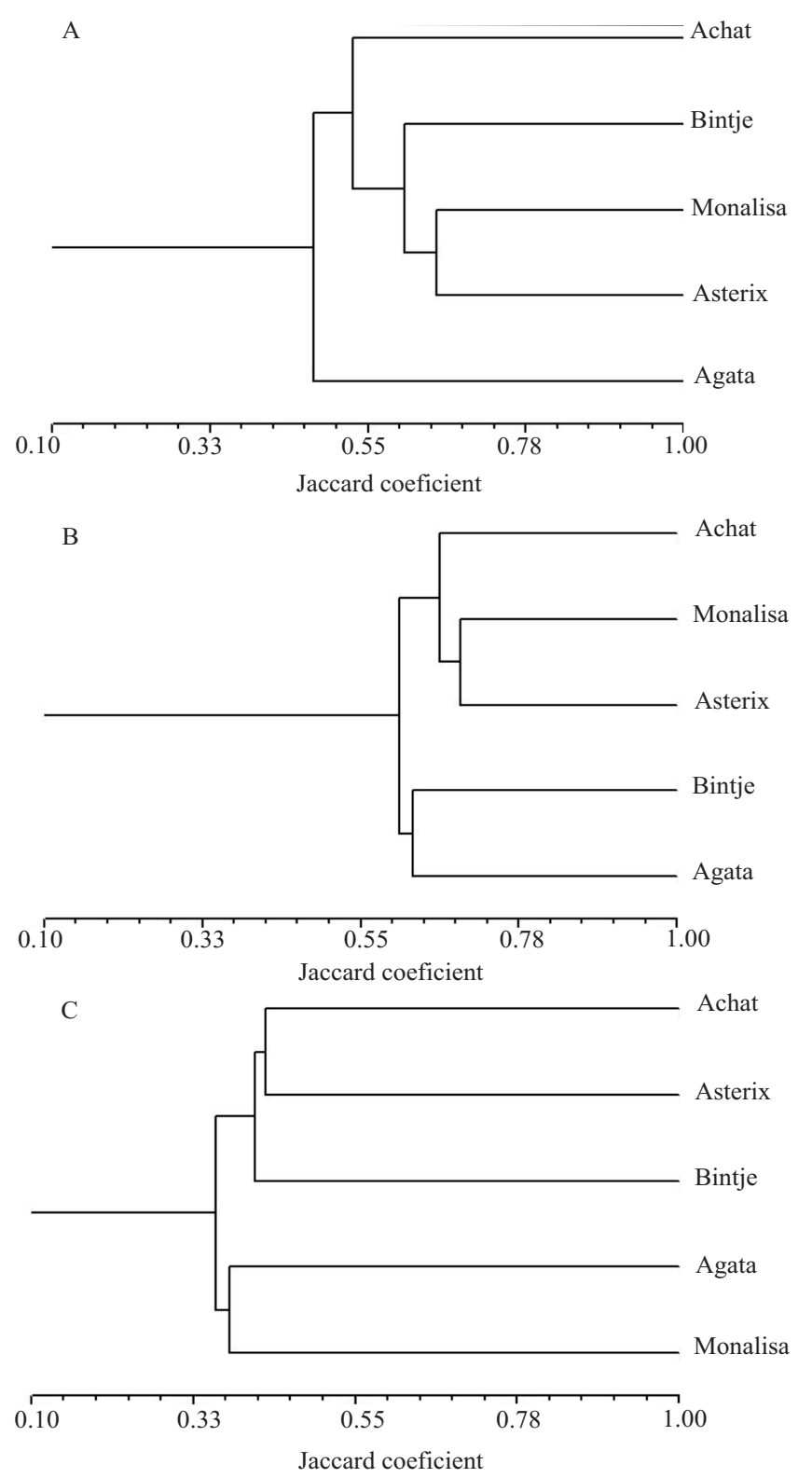

Figure 2. Similarity dendrograms representing the bacterial communities associated to the rhizosphere of different potato cultivars, constructed with data from the matrix generated by the Jaccard similarity coefficient, using UPGMA grouping method. A, plants collected at 15 days after germination (DAG) - first sampling date; B, $30 \mathrm{DAG}$ - second sampling date; C, 60 DAG - third sampling date. 
might be a function of the different maturation stages specific to each cultivar, which might have influenced the different types and amounts of root exudates. The root associated bacterial community is usually dynamic and can be highly affected by the plant developmental stage (Roesti et al., 2006).

The PCA grouping of the rhizosphere associated bacterial community is presented at Figure 3. The sum of the two first components explain 70.5, 58.2 and 60.6\% of the information for the first, second e third sampling dates, respectively. Once the PC explain the maximum variance of the studied variables (Jöreskog et al., 1976), the PCA allows a better demonstration of the observed differences between the potato cultivars.

The PCA compared with the similarity index grouping analysis provides more details of the interactions between the studied variables, once it mitigates data variation into several components, and allows a multidimensional view of the data. The PCA complements the information of the similarity dendrograms, helping the interpretation of data. The $\mathrm{X}$ axis is usually the most important to explain most of data variation.

Difference between the $\mathrm{X}$ and $\mathrm{Y}$ axes with our data was $10 \%$ maximum, indicating that both axes, in the three sampling dates, provided the same information. 'Achat', 'Monalisa' and 'Asterix' are usually at the same cluster, while 'Agata' is always apart (Figure $3 \mathrm{~A}$ ). 'Bintje' only in the second sampling date, is at a different cluster from 'Achat', 'Monalisa' and 'Asterix' (Figure 3 B). At Y axis, 'Achat' tends to locate far from 'Monalisa' and 'Asterix' (Figure 3). From a total of 17 morpho-physiological characteristics, 'Achat' shares only three of them with 'Monalisa' and 'Asterix', while the later two cultivars share seven of the characteristics (Table 1). This higher number of shared characteristics between 'Monalisa' and 'Asterix' indicates that they might be physiologically similar, and this is probably the cause of their grouping at the PCA.

The different grouping observed at the PCA (Figure 3) was a function of the sampling dates. However, for 'Agata', a distinct group was detected, placing this cultivar apart from the others in the three sampling dates. 'Agata' presents the most distinct morpho-physiological characteristics, when compared with the other cultivars (sprout color, number of stems per plant, plant height, tuber shape and tuber skin color), which might be associated with the observed clustering. Similar results were presented by Thomas et al. (2006) for somaclonal variants of Camellia spp. The authors reported that these variants could be divided into two morphological groups, and that some of them with similar morphological
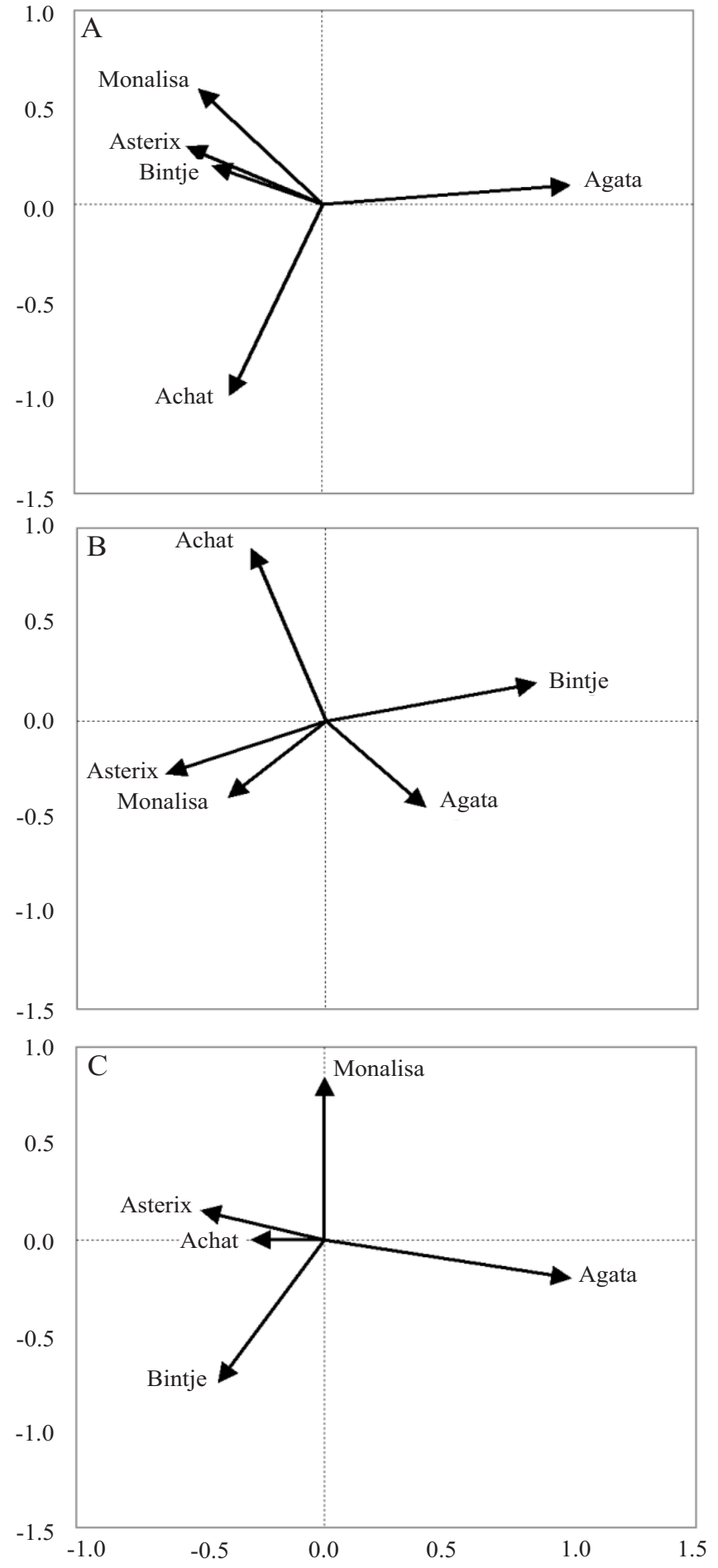

Figure 3. PCA grouping of the bacterial community associated to the rhizospheres of different potato cultivars: A, first sampling date; $\mathrm{B}$, second sampling date; $\mathrm{C}$, third sampling date. First sampling date: CP1, 40.1\%, CP2, 30.4\%; second sampling date: $\mathrm{CP} 1,31.3 \%, \mathrm{CP} 2,26.9 \%$; and third sampling date: $\mathrm{CP} 1,33.8 \%, \mathrm{CP} 2,26.8 \%$. 
characteristics could be also grouped by their similar physiological characteristics.

In the first sampling date, a cluster with the cultivars Monalisa, Asterix and Bintje (Figure $3 \mathrm{~A}$ ) was formed. In the second sampling date (Figure $3 \mathrm{~B}$ ), 'Bintje' migrated to another group, apart from the other cultivars, shifting a little back in the third sampling date (Figure $3 \mathrm{C}$ ). This cultivar is distinct from the other ones, in relation to its morpho-physiological characteristics, although it shares some few similar characteristics with the 'Achat', 'Monalisa' and 'Asterix' (Table 1), probably leading to the observed grouping with the former cultivars at least at two developmental stages. 'Monalisa' also shifts, on the $\mathrm{X}$ axis, in direction of the cultivar Agata from the first to the third sampling date. Both are early cultivars and, probably, this characteristic is reflected by the similar profile of the soil bacterial community, at the end of the growth cycle of the plants.

'Achat' is different from 'Monalisa' and 'Asterix', mainly in leaf color, plant height and vigor. This might be reflected at the physiological level, resulting in the exudation of different compounds, which, in turn, affect the root bacterial community structure.

Considering the clustering at the $\mathrm{Y}$ axis, the early cycle characteristic of 'Monalisa' and 'Agata' contributed to their grouping, which was also observed for maize (Silva et al., 2003) and wheat (Roesti et al., 2006).

The data of this work indicate that the grouping of the bacterial communities associated to potato cultivars is related to some morpho-physiological characteristics. This is also supported by the fact that the chemical composition of root exudates is dependent on plant species, cultivar, nutritional status, age, biotic or abiotic stress, and other environmental factors, which will, at last, affect the microbial community present at the rhizosphere (Mahaffee \& Kloepper, 1997; Griffiths et al., 1999).

\section{Conclusions}

1. Different potato cultivars show distinct PCRDGGE profiles, as a result of a selection process of the rhizosphere bacterial community, controlled by potato cultivar; cultivars resembling their morpho-physiological characteristics show the closest PCR-DGGE profiles.

2 . The similarity among bacterial communities associated to the rhizosphere of different potato cultivars decreases along the plant growth period.

3. The PCR-DGGE technique is suitable to detect the effect of potato cultivar on the bacterial community associated to potato rhizosphere.

\section{Acknowledgements}

To Coordenação de Aperfeiçoamento de Pessoal de Nível Superior, Embrapa Agrobiologia, and Embrapa Hortaliças, for financial and technical support.

\section{References}

ABBA. Associação Brasileira da Batata. Available on: http://www.abbabatatabrasileira.com.br. Accessed on: 7 Nov. 2005.

ABOIM, M.C.R.; COUTINHO, H.L.C.; PEIXOTO, R.S.; BARBOSA, J.C.; ROSADO, A.S. Soil bacterial community structure and soil quality in a slash-and-burn cultivation system in Southeastern Brazil. Applied Soil Ecology, v.38, p.100-108, 2008.

ÁVILA, A.C.; LOPES, C.A.; FRANÇA, F.H.; REIFSCHNEIDER, F.J.B.; HENZ, G.P.; BUSO, J.A.; FURUMOTO, O. A cultura da batata. Brasília: Embrapa Comunicação para Transferência de Tecnologia, 1999. 184p. (Coleção Plantar, 42).

BERGGREN, I.; ALSTRÖM, S.; VUURDE, J.W.L. van; MÅRTENSSON, A.M. Rhizoplane colonization of peas by Rhizobium leguminosarum bv. viceae and a deleterious Pseudomonas putida. FEMS Microbiology Ecology, v.52, p.71-78, 2005.

BUSHBY, H.V.A. Colonization of rhizospheres by Bradyrhizobium sp. in relation to strain persistance and nodulation of some pasture legumes. Soil Biology and Biochemistry, v.25, p.597-605, 1993.

GELSOMINO, A.; KEIJZER-WOLTERS, A.C.; CACCO, G.; ELSAS, J.D. van. Assessment of bacterial community structure in soil by polymerase chain reaction and denaturing gradient gel electrophoresis. Journal of Microbiological Methods, v.38, p.1-15, 1999.

GOMES, N.C.M.; FAGBOLA, O.; COSTA, R.; RUMJANEK, N.G.; BUCHNER, A.; MENDONA-HAGLER, L.; SMALLA, K. Dynamics of fungal communities in bulk and maize rhizosphere soil in the Tropics. Applied and Environmental Microbiology, v.69, p.3758-3766, 2003.

GRAYER, R.J.; VIEIRA, R.F.; PRICE, A.M.; KITE, G.C.; SIMON, J.E.; PATON, A.J. Characterization of cultivars within species of Ocimum by exudate flavonoid profiles. Biochemical Systematics and Ecology, v.32, p.901-913, 2004.

GRIFFITHS, B.S.; RITZ, K.; EBBLEWHITE, N.; DOBSON, G. Soil microbial community structure: effects of substrate loading rates. Soil Biology and Biochemistry, v.31, p.145-153, 1999.

GU, Y-H.; MAZZOLA, M. Modification of fluorescent pseudomonad community and control of apple replant disease induced in a wheat cultivar-specific manner. Applied Soil Ecology, v.24, p.57-72, 2003.

GUPTA, A.; RAI, V.; BAGDWAL, N.; GOEL, R. In situ characterization of mercury-resistant growth-promoting fluorescent pseudomonads. Microbiological Research, v.160, p.385-388, 2005.

HILBECK, A.; ANDOW, D.A. Environmental risk assessment of genetically modified organisms: a case study of Bt maize in Kenya. Cambridge: CABI Pub., 2004. v.1. 304p. 
IBEKWE, A.M.; GRIEVE, C.M. Changes in developing plant microbial community structure as affected by contaminated water. FEMS Microbiology Ecology, v.48, p.239-248, 2004.

JABUOMSKI, R.E.; FURUMOTO, O. Característica das cultivares. In: REIFSCHNEIDER, F.J.B. (Coord.). Produção de batata. Brasília: Linha gráfica, 1987. p.6-11.

JÖRESKOG, K.G.; KLOVAN, J.E.; REYMENT, R.A. Geological factor analysis. Amsterdam: Elsevier Publ. Co., 1976. 178p.

KATO-NOGUCHI H.; INO, T. Concentration and release level of momilactone B in the seedlings of eight rice cultivars. Journal of Plant Physiology, v.162, p.965-969, 2005.

KERDCHOECHUEN, O. Methane emission in four rice varieties as related to sugars and organic acids of roots and root exudates and biomass yield. Agriculture, Ecosystems and Environment, v.108, p.155-163, 2005.

KOZDRÓJ, J.; ELSAS, J.D. van. Structural diversity of microbial communities in arable soils of a heavily industrialised area determined by PCR-DGGE fingerprinting and FAME profiling. Applied Soil Ecology, v.17, p.31-42, 2001.

MACDONALD, L.M.; PATERSON, E.; DAWSON, L.A.; McDONALD, A.J.S. Short-term effects of defoliation on the soil microbial community associated with two contrasting Lolium perenne cultivars. Soil Biology and Biochemistry, v.36, p.489-498, 2004.

MAHAFFEE, W.F.; KLOEPPER, J.W. Bacterial communities of the rhizosphere and endorhiza associated with field-grown cucumber plants inoculated with a plant growth-promoting rhizobacterium or its genetically modified derivative. Canadian Journal of Microbiology, v.43, p.344-353, 1997.

MARILLEY, L.; ARAGNO, M. Phylogenetic diversity of bacterial communities differing in degree of proximity of Lolium perenne and Trifolium repens roots. Applied Soil Ecology, v.13, p.127-136, 1999.

NIVAA. Netherlands: catalogue of potato varieties. The Hague: Nivaa, 2003. 263p.
OLSSON, S.; PERSSON, P. The composition of bacterial populations in soil fractions differing in their degree of adherence to barley roots. Applied Soil Ecology, v.12, p.205-215, 1999.

PICARD, C.; BOSCO, M. Maize heterosis affects the structure and dynamics of indigenous rhizospheric auxins-producing Pseudomonas populations. FEMS Microbiology Ecology, v.53, p.349-357, 2005.

ROESTI, D.; GAUR, R.; JOHRI, B.N.; IMFELD, G.; SHARMA, S.; KAWALJEET, K.; ARAGNO, M. Plant growth stage, fertiliser management and bio-inoculation of arbuscular mycorrhizal fungi and plant growth promoting rhizobacteria affect the rhizobacterial community structure in rain-fed wheat fields. Soil Biology and Biochemistry, v.38, p.1111-1120, 2006.

SCHWIEGER, F.; TEBBE, C.C. A new approach to utilize PCRsingle strand conformation polymorphism for $16 \mathrm{~S}$ rDNA gene-based microbial community analysis. Applied and Environmental Microbiology, v.64, p.4870-4876, 1998.

SILVA, K.R.A.; SALLES, J.F.; SELDIN, L.; ELSAS, J.D. van. Application of a novel Paenibacillus-specific PCR-DGGE method and sequence analysis to assess the diversity of Paenibacillus spp. in the maize rhizosphere. Journal of Microbiological Methods, v.54, p.213-231, 2003.

SUNG, K.; KIM, J.; MUNSTER, C.L.; CORAPCIOGLU, M.Y.; PARK, S.; DREW, M.C.; CHANG, Y.Y. A simple approach to modeling microbial biomass in the rhizosphere. Ecological Modelling, v.190, p.277-286, 2006.

THOMAS, J.; RAJ KUMAR, R.; MANDAL, A.K.A. Metabolite profiling and characterization of somaclonal variants in tea (Camellia spp.) for identifying productive and quality accession. Phytochemistry, v.67, p.1136-1142, 2006.

XAVIER, G.R.; SILVA, F.V.; ZILLI, J.E.; RUMJANEK, N.G. Adaptação de método para extração de DNA de microrganismos associados a raízes de plantas. Seropédica: Embrapa Agrobiologia, 2004. 24p. (Embrapa Agrobiologia. Documentos, 171). 